UNRAM Law Review is licensed under a Creative Commons Attribution 4.0 International License, which permits unrestricted use, distribution, and reproduction in any medium, provided the original work is properly cited. p-ISSN: 2548-9267 | e-ISSN : 2549-2365, Open Access at : http://unramlawreview.unram.ac.id/index.php/ulr

\begin{tabular}{c|c|c|c|c|}
\hline Volume & Issue & Page & October & p-ISSN: 2548-9267 \\
4 & 2 & $193-204$ & 2020 & e-ISSN : 2549-2365
\end{tabular}

\title{
Mechanism of Business Contract Drafting in Supporting Economic Activities
}

\author{
Muhammad Sood \\ Faculty of Law, University of Mataram \\ Email:muhammad_sood@yahoo.com
}

\begin{abstract}
The development of business contracts in supporting economic activities, especially in the trade sector, is inseparable from developments in the field of law. Thus, economic actors should understand the contract design method. This article aims to analyze the regulations of business contracts both nationally and internationally, and analize the mechanism of business contract draftingin supporting economic activity. This article is sourced from the results of normative legal research; therefore the method of approach used is the legal approach and conceptual approach. The results of the study indicates that the legal sources which form the basis for regulating business contracts include national law as regulated in Article 1457-1540 of the Civil Code; contract documents; international agreements in the field of contract; court decisions regarding business contracts; and doctrines in the field of contract law. The business contract mechanism includes 3 stages, namely: 1) Pre contractual includes: negotiations on the delivery, delivery and payment of goods; risk of loss if there is a default and procedure for resolving contractual problems; make a Memorandum of Understanding as an initial guideline for the understanding of the parties; Feasibility study concerning the prospects of business contracts made by the parties; 2) Contractual or contractual arrangements include, writing the initial manuscript, revising the manuscript, exchanging draft contracts, revising and writing the final manuscript, and signing of the contract. 3) Contract contractual or contract completion where the parties are responsible for providing guarantees or guarantees that the agreed contract is executed and completed properly. Understanding the mechanism of contract design will facilitate business activities carried out by the parties.
\end{abstract}

Keywords: mechanism; contract design; business; parties

\section{INTRODUCTION}

Business contract is a written agreement between the parties, that is, between the party offering goods or services and the party receiving the offer. With the acceptance of the offer, a legal relationship or agreement has been reached between the parties, meaning that the parties have been bound to fulfill their achievements and counter-achievements, or have legally created rights and obligations for the parties. Business contracts in very rapid development; this is also in line with the increasingly smooth circulation of goods, services and capital, which is also supported by the ability of information technology, telecommunications and transportation both nationally and internationally.

The definition of an international business contract is an agreement that occurs in business activities between two or more people from different countries to fulfill their 
rights and obligations based on the agreement made. According to Sudargo Gautama, an international contract is a national contract that contains foreign elements ${ }^{1}$.

Business contracts must be interpreted in a broad sense, as it is a legal relationship that gives the rights and obligations of the parties that are not only related to the trade of goods between countries (export imports). But also includes trade in services, including contracts related to investment activities, finance, construction, transportation, and even contracts made in electronic form or called electronic commercial (e-commerce). Thus, that the contract development business not only includes legal relations that are still conventional but also has entered the era of modern development.

The development of business contracts in order to support economic activities especially in the trade and investment sector are inseparable from developments in the field of contract law both nationally and internationally. Thus, contract law is needed as a rule of law in regulating the legal relations of the parties both in making and implementing, as well as in resolving contractual issues. Therefore, the parties should refer to the rule of contract law as a legal instrument in making business contracts, whether the contract is unilateral or bilateral, in the national or international scope.

Caterin Elliott and Frances Quinn, in his book Contract Law, stated,

"In order to understand the contract law in offer and acceptance, you need to understand the concept of unilateral and bilateral contract. Most contracts are bilateral. This mean that each parties take on an obligation usually by promising the other something, for example an promises to sell something and Ben to buy it (Although contract where these are mutual obligation are always called bilateral, there may in fact be more the two parties to such a contract)". ${ }^{2}$

Based on this opinion, to understand the business contracts law in terms of offer and acceptance, it is necessary to understand the concept of business contracts, both unilateral and bilateral. Most contracts are bilateral in nature this means that each party is obliged to fulfill its achievements. This is usually on the basis of agreements with other parties. For example the first party promises to sell something, and the other party promises to buy it. Although in a contract there is a joint obligation between the buyer and seller which is called a bilateral contract, but it is possible that actually in the contract there are more than two parties (multilateral). Contractual relationship can be seen in trading and investment activities that not only occur between the seller (exporter) and the buyer (importer) but involve other parties, namely the bank (issuing bank and advising bank).By understanding mechanism of business contracts in supporting economic activities, especially in the trade and investment sector, which is needed for business actors as parties involved in business relations.

Based on the description above, then the problem in this article are, what is the legal arrangement on business contracts both nationally and internationally; and how the mechanism or procedures for designing business contracts in supporting economic activities in Indonesia.

\footnotetext{
${ }^{1}$ Sudargo Gautama. (1976). International Trade Contract. Bandung: Alumni, p. 7.

${ }^{2}$ Elliott and Frances Quinn. (2005). Contract Law, Fifth Edition. London, England: Person Educated Limited, p. 1.
} 


\section{METHOD}

This article is sourced from the results of a normative research that analyzes various legal norms about the mechanism of business contracts drafting in an effort to support economic activity. The approach method used includes, approaching statute approach and conceptual approach using documentation techniques (literature study) to obtain legal materials including primary, secondary and tertiary legal materials. Then the legal materials that have been collected next evaluated and analyzed qualitatively.

\section{ANALYSIS AND DISCUSSION}

\section{Regulation of Business Contracts both Nationally And Internationally}

Various legal sources as a reference for business contracts in supporting economic activities, both material and formal legal sources, in national and international scope consist of: ${ }^{3}$

\section{a. National Law}

National law is the primary source of law in contract law; this was stated by Sudargo Gautama in Huala Adolf that international contracts are national contract law with foreign elementsmeaning that contracts are subject to one of the national legal systems in the field of commercial or commercial law. For example, the contract rules or the validity of the agreement in Indonesia are listed in the Civil Code and other rules relating to the object of the contract. ${ }^{4}$

In making contracts, each country has general and specific provisions. General provisions regarding contracts (general contract), regulated in Book Three of the Civil Code Act which also regulates principles and contracts. This provision applies to all contracts made by the parties such as contract of sale, lease, and exchange and so on. While special provisions concerning contract (specific contract), such as concerning the sale and purchase agreement stipulated in Article 1457 through Article 1540 of the Civil Code. Other provisions which constitute the source of contract law in national law are statutory regulations, whether directly or indirectly related to the object of the contract, for example legal rules concerning trade, investment, labor, taxation, consumer protection, environmental protection, licensing and so on.

\section{b. Contract Document}

Contract documents are lex specialist rules from rules or legal principles. The rules in the contract document mainly concerning the rights and obligations of the parties as the essential rules. In addition, to the choice of law in the form of national law, the content or provisions of the article in the contract document is the main law, even this is the most important for the parties. This can apply based on the principle of agreement that applies to the parties as regulated in Article 1338 which states that "all treaties made legally apply as a law to those who make them". As such, the agreement cannot be withdrawn other than by agreement of the two parties, or for reasons stated by the law which are declared sufficient for that. ${ }^{5}$

\footnotetext{
${ }^{3}$ Huala Adolf. (2006). Fundamentals of International Contract Law. Bandung: PT. Refika Aditama, p. 7.

${ }^{4}$ Ibid.

${ }^{5}$ Ibid., p. 70-71.
} 


\section{c. International Agreement (Convention)}

International agreements in the field of contract law are the primary source of law, as well as national law and contract documents. This legal source is no less important than the other main legal sources in regulating and influencing contracts made by the parties. Thus, international agreements are one part of the source of international law, because international law is an important source of contract law. ${ }^{6}$

Furthermore,Huala Adolf stated that international law was able to play a role in contributing to the contractual law arrangements. This refers to Sunaryati Hartono's opinion, which the enforcement of international law can be carried out on commercial contracts in the field of Foreign Investment; such contracts apply agreements or international law. International agreements can be bilateral agreements or apply between two countries; and multilateral agreements that apply to more than two countries. It application in the fields of navigation, trade or friendship can be taken as example. ${ }^{7}$

Various international regulations or conventions governing business contracts as follows: ${ }^{8}$

1) UNIDROIT Principles of International Contract 2010, General Principles on Business Contracts known as the UNIDROIT Principles of International Contract, are the principle of harmonization in the field of Contract Law from various different legal systems, both Civil Law; Common Law; Socialist Legality; Shariah; or Canonic Law ...

2) UNCITRALLaw Model onE-Commerce of 1996 with Guide to Enactment, withAdditional Article 5 bis as Adopted in 1998, this Regulation applies to any information in the form of data messages that are used in the context of commercial activities. Data messages are defined as information that is generated, sent, received or collected electronically, optically or in a similar manner, including but not limited to: electronic data interchange (EDI), electronic mail, telegram, telex or tele copy

3) United Nations Convention on Contracts for International Sales of Goods (UNC-CISG) 1980. This convention regulates the sale and purchase of international goods which is quite comprehensive and describes the results of harmonization of various different legal systems. This convention tries to formulate the rights and obligations of the parties in the sale and purchase of international goods transparently. As of September 30, 2011, this Convention has been ratified by 77 countries which reflect two-thirds of the volume of international trade.

\section{d. Customs in International Business Contracts}

International customs (hebits) in business contracts are one source of law and become a guide in interpreting international business contracts. International customs in trading activities have generally been recognized as a rule of law. The source of this law is also called LexMercatoria (the law of business people), this law was born and developed because of practices or habits practiced by business people themselves, and is considered binding between them. The acceptance of LexMercatoria as a binding legal source gave rise to controversy from various scholars, not debating its status as an international custom but rather its acceptance

${ }^{6}$ Ibid., p. 77

${ }^{7}$ Ibid.

${ }^{8}$ Ida Bagus Rahmadi Supancana. (2011). Development of International Trade Contract Law. National Legal Development Agency (NLDA), p. 23.

196 Muhammad Sood | Mechanism of Business Contract Drafting in Supporting Economic... 
into national law. However, LexMercatoria in its development has increasingly recognized existence and has binding power.

The binding international trade habits have been codified by international institutions or bodies in the field of trade. For examples of these codified or written habits include in: ${ }^{9}$

1) Uniform Custom for Documentary Credits (UCP) 500, is a contract document that contains the rules of business policy in the banking sector, especially in the case of payments through documented credit. This UCP in banking law has been widely used as a reference by various countries, especially as a provision in payment of international trade using Letters of Credit (L/C).

2) Incoterms 2000 is an international provision governing trade conditions related to the transportation of goods by ship. For example, the terms FOB or CIF are terms generally understood by business people. This term was later codified by the ICC into a document called Incoterms 2000.

3) Standard contract forms in the field of construction issued by the Engineer Organization in the world are FIDIC (Federation Internationale des IngenieursndesConseils). This document contains the forms of standard contracts which are also known as Standard Form Contracts (International Construction Contract-FIDIC Condition).

\section{e. Court Decision}

The court decision is an additional source of law which is quite important to know the position of the court against the rules of international contracts including the position of the court against the legal sources listed above. This Court's Decision is decisive in the sense that the decision then followed by subsequent courts consistently or even later becomes jurisprudence. The decision has clearly demonstrated the importance or significance of the development of contract law, including international contract law. ${ }^{10}$

Furthermore, Huala Adolf stated that in a country with a Civil Law system such as Indonesia, the court's decision regarding international contracts has a persuasive and decisive legal value. Court decisions and arguments are actually (collections) of opinions of individuals who are law graduates. Therefore the opinion of the court's decision has a value that is influential (persuasive) to the existence of a certain law. ${ }^{11}$

\section{f. Doctrines}

Doctrine is the opinion of leading experts / scholars in the field of law whose expertise is recognized as a very important source of law as an additional source of law. This means that doctrine can be used as a reference to emphasize whether or not a legal provision exists regarding an object of the contract. This doctrine can be in the form of written literature such as, reference books, scientific articles and so on. It also can take the form of notes in the form of opinions in a process of drafting an international treaty (travauxpreparatoire). Even doctrine can also be reflected in the decisions of international courts.Both arbitration and international courts and courts. Judges in various international tribunals as well as international courts include law graduates who are generally from among the world's leading tertiary institutions. ${ }^{12}$

\footnotetext{
${ }^{9}$ Ibid., p. 73.

${ }^{10}$ Ibid., p. 75 .

${ }^{11}$ Ibid.

${ }^{12}$ Ibid., 76.
} 


\section{Procedure of Business Contracts Drafting for Supporting Economic Activities}

Designing a contract (contract drafting) is regulating and planning the structure, anatomy, and substance of the contract made by the parties. A contract structure is an arrangement of contracts to be made or designed by the parties. Anatomy of a contract is related to the location and relationship between one part with another part. The substance of the contract is the content that will be contained in the contract to be designed by the parties. The substance of the contract is negotiated by the parties and some have been determined unilaterally by one of the parties or what is called a standard contract. ${ }^{13}$

\section{a. Stages in Business Contracts Drafting}

The stages in the design of the contract (contract Drafting), whether the contract is carried out in the scope ofdomestic (within a country), andbetween countries(international) generally includes 3 stages, namely, pre-contractual, contractual and contractual, namely.

\section{1) Pre Contractual}

In this stage the parties are exploring each other through negotiation or bargaining efforts, making a Memory of Understanding, until consensus is reached.

a. Negotiation

Negotiation according to the Indonesian Dictionary, interpreted by "negotiation" is "the bargaining process by way of negotiations in order to reach mutual agreement between oneparty(groupororganization)andanotherparty(groupororganization)". ${ }^{14}$ Meanwhile, according to HikmahantoJuwana negotiation refers to: "a process in which the parties, who have different views on one or several specific things in a business contract, make a compromise on these differences of opinion. ${ }^{15}$ Thus, negotiation is a bargaining process to reach agreement on a cooperation in which the parties give concessions to each other.

Lack of comprehention of business actor in negotiating techniques in the context of making business contracts, it will cause legal problems in the future. Therefore, the negotiation process in making contracts is the basis for determining the rights and obligations of the parties in a business activity. The negotiation process is the basis of reference before the agreement is formulated in the form of a business contract preparation clause.

At the negotiation stage, things that must be considered as follows: ${ }^{16}$

1) The mechanism of communicating between parties or discussing a matter to reach consensus (agreement) on the main points of the agreement.

2) The parties must determine how to send and deliver goods; the method of payment of goods whether directly by cash or installment funds, or through bank services by using securities such as cheque or Letters of Credit (L/C);

3) If there is a failure (default or overmacht) in a business contract, both in the payment of goods, as well as the delivery and delivery of goods, it must be determined who bears the risk and loss, because that possibility can occur

\footnotetext{
${ }^{13}$ Salim HS (et.al.). (2007). Perancangan Kontrak dan Memorandum of Understanding (MoU). Jakarta: Sinar Grafika, p. 1.

14 Departemen Pendidikan dan Kebudayaan. (1989). Kamus Besar Bahasa Indonesia. Jakarta: Balai Pustaka, p. 21.

${ }^{15}$ Adi Gunawan, Advokat Senior, Founder \& Managing Partner of Andi Gunawan \& Associates Law Firm, Teknik Nego siasi Kontrak, From: http://www.justitiatraining.co.id, (Accesed: August 22, 2017).

${ }^{16}$ Ibid.
} 
4) The parties must also determine the procedure and mechanism for resolving contract issues in the event of default, whether through litigation, through non-litigation channels, such as mediation, conciliation and arbitration.

If this negotiation stage is successfully conducted, then the next stage is to make a Memorandum of Understanding (MoU) which is the documentation of the results of the initial negotiations in written form. The MoU is important as a guide for the parties in further negotiations or as a basis for conducting a feasibility study.

b. Memorandum of Understending.

Memorandum of Understanding $(\mathrm{MoU})$ is an informal memorandum/warning letter which is a form of communication that includes, among others, advice, direction and information. ${ }^{17}$ According to ErmanRajagukguk in Salim HSMoUis "document containing mutual understanding between parties before the agreement is made". The contents of the Memorandum of Understanding must be included in the contract, so that it has binding power". ${ }^{18}$

The elements that characterize the Memorandum of Understanding (MoU), namely:

1) Its contents are concise, containing only the main points, which are introductory covers only one page,

2) Determined the validity period, for example 1 month, 6 months or a year.

3) If within this time period is not followed up with the signing of a more detailed agreement, the Memorandum of Understanding (MoU) will be canceled, unless extended based on the agreement of the parties.

4) MoUs are usually made in the form of an underhand agreement without any stamp duty.

5) Usually there are no compulsory obligations to the parties to make a more detailed agreement after the signing of the MoU.

Based on the description above that at this stage each party signed the $\mathrm{MoU}$ as an initial guideline sign of an understanding between the parties. MoU basically can stand alone and does not require a master agreement. The elements contained in the MoU are preliminary agreements, and the contents of the material are the main points set forth in a business contract.

c. Feasibility study

After the parties obtain an MoU as a guideline or a temporary guide, then it is continued with the feasibility study stage (due diligent) to see the level of feasibility and prospects of the business contract made by the parties from various perspectives on why the contract is needed, for example regarding contracts relating to investment activities, employment, buying and selling, marketing of goods and services, exportimport, shipping and transportation of goods, and so on. The results of the feasibility study are needed in assessing whether or not the contract should be continued or carried out further negotiations. if necessary, further negotiations will be held and the results outlined in the contract. ${ }^{19}$

\footnotetext{
${ }^{17}$ Salim HS et al,. Op. cit, p. 91.

${ }^{18}$ Munir Fuady. (1999). Contract Law, From a Business Law Perspective. Bandung: PT. Citra AdityaBakti, p. 43.

${ }^{19}$ Munir Fuady. (1999). Contract Law, From a Business Law Perspective. Bandung: PT. Citra AdityaBakti, p. 43.
} 
Various aspects must be reviewed as part of the feasibility study in order to support the implementation of business contracts, namely: ${ }^{20}$

1) The legal aspect which is related to all the legality of a business plan to be implemented by the parties, including legal provisions such as, problems; certificate of incorporation of the company from the local notary, whether in the form of Limited Company, CV (Comanditaire Venootshaf) or in the form of other business entities; Taxpayer Identification Number (NPWP); Company registration certificate; Business location permit from the local government; Partnership certificate from the local government; and Trading Business License (TBL) and so on.

2) The social aspect which is related to the impact given to the surrounding community due to the existence of a business activity such as increasingly crowded and smooth traffic communication lines, electricity and other lighting, education of the local community.

3) Economic aspects, related to employment and business opportunities for the local community; level of income per capita of the population; whether the business is able to increase national income, or the average local wage, or regional minimum wage.

4) Cultural aspects, related to the impact of economic activities on the lives of local people, especially on the customs of local customs and institutions that have lived in the community.

5) The environmental aspect which is related to the impact of economic activities on environmental functioning, whether it does not cause environmental pollution and damage, and how to prevent, cope with and control if it has an impact on the environment.

6) Other aspects such as technical and technological aspects are related to the selection of locations, tools, which are in accordance with the desired results, lay out, and selection of appropriate technology; management aspects are concerned with development and operations; and financial aspects concerning the source of funds to be obtained and the projected return with the level of capital costs and the source of funds concerned.

\section{2) Contractual}

The contractual stage is the most important and decisive stage in contract making. This contract drafting phase needs carefulness from the parties, because if there is a mistake in this stage it will cause problems in the implementation. There are several stages in the preparation of a business contract including, writing the initial script, revising the manuscript, exchanging draft contracts, revising and writing the final manuscript, and signing of the contract, this can be described as follows: ${ }^{21}$

a) Writing the Initial Manuscript of a Business Contract

In writing a business contract the parties must pay attention to several things namely:

1) Determination of Title Business contracts must be clear, concise and adapted to the contents of the contract and the legal provisions governing it.

2) Introduction Part A business contract must contain the purpose and purpose of

\footnotetext{
${ }^{20}$ Suad Husnan and Suwarsono. (1991). Project Feasibility Study. Yogyakarta: UPP-AMP YKPN, p.17-20.

${ }^{21}$ Ibid.
} 
making a business contract, why this business contract is important to be implemented both economically and for people's lives.

3) The contents of the contract are the core of the contract, in which clauses include: the object of the contract, the price or value of the goods / services promised; the rights and obligations of the parties to the contract must be clear in the contract; Choice of law and choice of forum in dispute resolution whether through litigation or non-litigation (mediation, conciliation, negotiation, or arbitration).

4) Closing Section contains procedures for ratification of the contract. The signing of the contract was carried out by the parties on stamped paper, and witnessed by witnesses from each party. If the contract is accompanied by a contract attachment, then basically the attachment can contain supporting documents, such as the format of the contract that accompanies the main contract, legal opinion format, and so on.

b) Exchanging the Draft of Contract

After the draft of business contract made by each party is completed, the next step is to exchange draft of contracts that have been made. The purpose of exchanging draft of contracts is to provide an opportunity for the parties to study the contents of the draft of contract that has been prepared. If one party disagrees with the draft of contract, the other party can propose or negotiate about what they disagree with. If the results of the negotiations have been agreed upon, then the proposal is included in the draf of contract. c) Revised manuscripts and Final Manuscript

The revision and writing of the final manuscript is the stage of checking or revising the draft contract that has been agreed for the last time, the revision is good for writing procedures such as letters / spelling that is inappropriately written, as well as for the substance or content in the contract that has been agreed. The writing of this final manuscript is the final writing of the contract made and agreed by the parties.

c) Contract Signing.

The contractsigning stagecarried outby the parties as the final partof thepre-contractual phase. Signing a contract by the parties is evidence that the parties are bound to carry out the contract that they have agreed on. Before the contract is signed, the parties must check the concept of the contract including the substance, language, editorial, numbers and letters and initials on each sheet of contract documents. To strengthen the agreement of the parties that the contract made is binding on the parties, the contract signing is often done before a Notary Officer witnessed by 2 witnesses from each party.

The signing of the contract in principle is proof that a legal event has taken place that gave birth to a legal relationship between the parties in business activities. Accordingly, the business contract entered into by the parties must comply with the legal principles of the agreement and fulfill the legal requirements of the agreement. This is so that the contract can become perfect evidence in court if a dispute arises. Therefore, the parties should rethink carefully any legal consequences that will occur before a business contract is signed so that the parties do not lose money in the future.

3) Post Contractual

Post Contractual is the stage of contract completion in which the parties are responsible for providing a guarantee that the contract agreed can be implemented and completed 
properly. At this stage it is also called the maintenance period and guarantees that there are no hidden defects or warranty phases. For example, an investment business contract between the governments as an order in the real estate sector (construction of buildings, bridges, highways). In this case the investor must be responsible for providing guarantees for building safety, even though the construction of the building has been completed. The responsibility usually lasts for 5 (five) years from the handover of the building to the order.

In the implementation of a contract the possibility of a dispute occurs difficult to avoid, in this case the parties are free to determine how the settlement will be taken if a dispute occurs in the future. The way to resolve the dispute must be explicitly stated in the contents of the contract. The parties can choose to settle the dispute through litigation (court) or outside the court (non litigation) or the so-called alternative dispute resolution such as mediation, conciliation, negotiation, and arbitration.

Based on the description above that the importance of designing business contracts in supporting economic activities, contract law is not only seen as a means of legal certainty, but also serves as a support for the continuity of development, both in providing a basis of certainty, a means of security and as a means of accelerating economic development process. It is clear that contract law is one of the means to determine the success or failure of such development as a business activity, especially since Indonesia will face globalization in the trade sector.

In order to make changes in the legal field, the problems faced are indeed quite complex, and we have very little courage to initiate change. We are trapped in a prolonged process of waiting, who knows how long the economic traffic will become more complicated, we deliberately turn a blind eye to the development of business contracts in the face of globalization in the trade and investment sectors. as if we leave economic traffic in the hands of new "habits" determined by economic interactions in the market. ${ }^{22}$

In supporting the implementation of business activities, especially in the trade and investment sector, an understanding of the regulation and mechanisms of contract design is necessary, both directly related to business activities, such as trade and investment as well as supporting regulations. These regulations included but not limited to import duties (tariffs) and non-tariffs, export quotas, intellectual property rights, investment, service trade, business license and franchise issues, financing issues related to the banking sector, insurance, customs, taxation; and other issues concerning the national interests of exporting and importing countries, such as environmental issues, small industry growth and so on. These norms are part of the study of business law, namely the legal rules governing activities such as the sale and purchase of goods and services, or export-import between one country and another, or relating to the activities of moving goods, services, labor capital and intellectual property rights.

Understandingthe mechanism of business contracts in supporting economic activities, especially in the trade and investment sector, is needed especially for business actors as partiesinvolved in business relations. This has becomevery importantandessential because there are still many economic actors who do not understand the terms and mechanisms

\footnotetext{
${ }^{22}$ T. Mulya Lubis, in Muhammad Sood. (2018). International Trade Law, Second Edition, Depok: Rajawali Pers, Raja Grafindo Persada, Depok, p. 12.
}

202 Muhammad Sood | Mechanism of Business Contract Drafting in Supporting Economic... 
of contract drafting. The importance is to understand the provisions and mechanisms for designing business contracts for economic actors, among others, to ensure the efficient and smooth functioning of security and market mechanisms for business actors; protect various types of business activities especially the types of Small and Medium Enterprises (SMEs) are the most vulnerable; business people can also know more about their rights and obligations and responsibilities when building a business. Thus, the business people will not deviate from the applicable provisions, so that in the end that in conducting business activities is not only aimed at seeking economic benefits, but is able to realize business attitudes and behavior that are fair, honest, healthy, dynamic, and just because they already have legal certainty and certainty of business rights.

\section{CONCLUSSIONS}

a. Various regulations of business contracts, include: National law as regulated in Article 1457 to Article 1540 of the Civil Code on sale and purchase; Contract documents regarding the rights and obligations of the parties based on consensual principles; International contractual agreements, UNIDROIT Principles of International Contract 2010, UNCITRAL Model Law on E-Commerce of 1996, United Nations Convention on Contracts for International Sales of Goods (UN -CISG), as referred to in LexMercatoria; Court decision as an additional source of law regarding business contracts; and Doctrines which are the opinions of experts in the field of contract law.

b. Procedureandmechanism of business contracts drafting for supporting economic activitiesboth in national and international scope, generally include 3 Stages:

1) Pre Contractual, including: Negotiation is a bargaining process to reach an agreement onthe delivery and payment of goods; risks and losses in the event of default or overmach, and procedures for resolving business contract problems; making a Memorandum of Understanding (MoU) as an initial guideline for understanding between the parties; and conduct a feasibility study to see the feasibility and prospect of business contracts made by the parties, so that the contract is required.

2) Contractual is the most important and decisive stage in contract making. At this stage, the contract text needs to be examined carefully by the parties; if there is a mistake it will cause problems in its implementation. There are several stages in the preparation of a business contract including, writing the initial draft, revising the manuscript, exchanging draft contracts, repairing and writing the final manuscript, and signing of the contract.

3) Post Contractual is the stage of contract completion in which the parties are responsible for providing a guarantee that the agreed contract is executed and completed properly. At this stage it is also called the maintenance period, and guarantees that there are no hidden defects, or warranty phases. In this case the parties are responsible for providing guarantees for the security of the promised object even though the rights and obligations of the parties have been fulfilled.

Based on the description above, an understanding of the mechanics of drafting business contracts in supporting economic activity, especially in the trade and investment sector is very necessary, especially for business actors involved in business relations. This becomes very essential because there are still many economic actors who do not understand the terms and 
mechanisms for drafting contracts to ensure security and market mechanisms efficiently and smoothly, so that they are able to understand their rights and obligations and responsibilities in developing their businesses

Comprehention of the mechanism for designing business contracts is not only important for academics but for business actors as parties involved in business relationships, in order to protect various types of business activities so that they understand the rights and obligations and responsibilities when building a business. Thus, business actors will not deviate from the applicable provisions, so that in the end they are able to realize business attitudes and behavior that are fair, honest, healthy, dynamic, and fair because they have a legal certainty in conducting business activities.

\section{Bibliography}

Books:

Elliott and Frances Quinn. (2005). Contract Law, Fifth Edition. London, England: Person Educated Limited.

Fuadi, Munir. (1999). Contract Law, From a Business Law Perspective. Bandung: PT. Citra AdityaBakti.

Gautama, Sudargo. (1976). International Trade Contracts. Bandung: Alumni.

Husnan, Suad and Suwarsono.(1991). Project Feasibility Study. Yogyakarta: UPP-AMP YKPN.

Salim HS et al. (2007). Contract Design \& Memorandum of Understanding (MoU). Jakarta: Sinar Grafika.

Supancana, Ida Bagus Rahmadi. (2011). Development of International Trade Contract Law. National Legal Development Agency (NLDA)

Sood, Muhammad. (2018). International Trade Law, Second Edition, Depok: Rajawali Pers, Raja GfindoPersada.

UNCITRAL. (1998). Model Law on Electronic Commerce. Article 1, Article 2 (a).

Department of Education and Culture. (1989). The Indonesian Dictionary. Jakarta: Balai Pustaka

World Wide Web:

Gunawan, Adi. Advokat Senior, Founder \& Managing Partner of AndiGunawan\& Associates Law Firm, Teknik Negosiasi Kontrak, From: http://www.justitiatraining.co.id, (Accesed: August 22, 2017). 